\title{
THE FEASIBILITY STUDY OF THE USE OF BRINY GROUNDWATER AND ZEOLITE IN THE PLAIN CONCRETE MIX DESIGN IN THE DIFFERENT CEMENT CONTENTS
}

\author{
Kami KABOOSI ${ }^{1, *}$, Mehran FADAVI ${ }^{2}$, Ehsan SETAYESH ${ }^{2}$ \\ ${ }^{1}$ Department of Water Engineering, Gorgan branch, Islamic Azad University, Gorgan, Iran. \\ ${ }^{2}$ Department of Civil Engineering, Gorgan branch, Islamic Azad University, Gorgan, Iran. \\ corresponding author: kkaboosi@yahoo.com.
}

\section{Abstract}

The present study was conducted to investigating interaction of three types of mixing water (tap water, briny groundwater and a mixture of their equal ratio), four levels of cement substitution with zeolite in the concrete mix design ( $0 \%, 10 \%, 20 \%$ and $30 \%)$, two levels of cement content $\left(250\right.$ and $\left.350 \mathrm{~kg} \cdot \mathrm{m}^{-3}\right)$ and seven curing ages $(3,7,28$, $56,90,180$ and 365 days) on compressive strength of concrete. In order to statistical analysis of data - a means that was not employed in the similar studies - the study was designed as a factorial experiment based on the completely randomized design with 168 treatments and three replications (totally 504 concrete specimens). The results of the analysis of variance (ANOVA) showed that neither of the two-, three- and four-way interactions of curing age with other factors were not statistically significant. This means that the gain rate of compressive strength of concrete by time was significantly similar in each possible combination of cement content, water type, and zeolite percentage. However, regarding the significant two- and threeway interactions of other studied factors, more attention should be paid to the results of these interactions than the simple effects of factors. Accordingly, based on the means comparison test (least significant difference: LSD), simultaneous use of unconventional waters with zeolite up to $20 \%$ in the cement content $350 \mathrm{~kg} \cdot \mathrm{m}^{-3}$ can be recommended in terms of compressive strength of concrete.
\end{abstract}

\author{
Keywords: \\ Compressive strength; \\ Curing age; \\ Mix design; \\ Mixing water: \\ Unconventional water.
}

\section{Introduction}

Water scarcity is one of the most important problems in human societies. At the same time, worldwide the construction industry consumes about 2.1 billion $\mathrm{m}^{3}$ of freshwater as mixing water excluding the water needed for curing and other consumptions in concrete production [1]. Therefore, continuous research is needed to find alternative water resources for the construction industry, especially in countries with severe water scarcity [2], such as Iran.

In the construction industry and in the scientific literature, potable water is known as mixing water. However, in the design codes, it is recommended that the compressive strength of concrete made with suspected water not to be less than $90 \%$ of one made with potable water [3-6]. According to this criterion, many studies were conducted to investigating unconventional water resources as mixing water of concrete, worldwide. For instance, the possibility studies for substitution of common mixing water with saline wastewater discharged from the seawater treatment plant [2, 7], seawater [89] and saline water [10] for the construction of concrete were conducted. The use of seawater in the plain concrete with the minimum cement content that was completely and permanently immersed in marine environments [11] and a mixture of desalinated water and saline groundwater in conventional concrete [11] were also reported. The results of a study showed that 7- and 14-days compressive strength of concrete made and cured with seawater (TDS and $\mathrm{pH}$ about $40000 \mathrm{mg} \cdot \mathrm{l}^{-1}$ and 2.8 , 
respectively) was greater than one made and cured with tap water, whereas its 28- and 90-days compressive strength was lower [7]. The reduction of the gain rate of compressive strength by time was attributed to the formation of salt crystallization [7-8]. Also, findings of Fattah et al. [2] showed that the use of salty wastewater discharged from the seawater treatment plant as mixing water of concrete, despite the high concentration of calcium, magnesium, and chloride (by 826, 2553 and $39426 \mathrm{mg} \cdot \mathrm{l}^{-1}$, respectively), did not have any negative effects on the compressive strength of concrete. Meantime, the results of another study showed that using seawater compared with tap water significantly increased the compressive strength of cement mortar and concrete at curing ages 3, 7 and 28 days [8]. However, it was reported that using the seawater as mixing water compared with tap water, in the different ratios of water to cement content, reduced the compressive strength of concrete at different curing ages up to 90 days by about $2 \%-10 \%$. This matter was attributed to the high concentration of chloride and sulfate in the seawater [9].

Zeolite is one of the abundant and cheap mineral additives in Iran, which its pozzolanic activity in the concrete was completely proven [12]. Although the reduction of compressive strength of concrete was observed due to zeolite application in some researches [12-15], it was generally reported that the optimum level of cement substitution with zeolite in the concrete mix design in terms of this property is between $10 \%$ and $30 \%[12,16-20]$. The increase of compressive strength of concrete due to the application of zeolite is the most known reason for its application in the mix design. This effect is attributed to the reaction between the significant amount of silicon dioxide $\left(\mathrm{SiO}_{2}\right)$ and aluminum oxide $\left(\mathrm{Al}_{2} \mathrm{O}_{3}\right)$ of zeolite with calcium hydroxide $\mid \mathrm{Ca}(\mathrm{OH})_{2}$ of cement. This reaction decreases $\mathrm{Ca}(\mathrm{OH})_{2}$ content of concrete and produces more volume of calcium silicate $\left(\mathrm{Ca}_{2} \mathrm{O}_{4} \mathrm{Si}\right)$, calcium aluminosilicate $\left(\mathrm{CaAl}_{2} \mathrm{Si}_{2} \mathrm{O}_{8}\right)$ and calcium silicate hydrate $(\mathrm{CSH})$ gel. These results in more filled voids and improve the concrete microstructure and finally increase the compressive strength of concrete [12, 19, 21-23]. However, the use of natural zeolite in the concrete mix design has more advantages including reduction of air pollution to carbon dioxide due to decreasing the cement consumption [2, 14, 21,24] and molecular sieving property and high cation exchange capacity of natural zeolite which can efficiently adsorb different contaminants in the concrete mix design and mitigate the adverse effects of these substances on the concrete [25]. For instance, the results of a study showed that the use of zeolite in concrete mix design resulted in a positive effect on the concrete resistance against some corrosive salts [26]. Moreover, the results of a review study showed that concrete permeability to water and chloride very apparently decreased when $5 \%$ to $30 \%$ of the natural zeolite was added into concrete mix design [20].

Because of the geological conditions and hydrogeological characteristics of the Northern and Eastern regions of Golestan province, Iran, especially its proximity to the Caspian Sea, the groundwater in this area is very salty. Due to lack of access to surface water resources with good quality in most months, civil and construction activities in this region are always dealing with the great challenges. Therefore, the possibility study of using unconventional water such as briny groundwater in this region is necessary. Moreover, with respect to the considerable properties of natural zeolite for improving concrete durability and reducing the adverse effects of contaminants of mixing water, the present study aimed at investigating the interaction of mixing water type $\times$ zeolite percentage $\times$ cement content $\times$ curing age. Also, in previous similar studies, the changes in compressive strength affected by zeolite percentage or water quality were expressed only in terms of percentage. Regarding the disability of this statement in determining whether there are any statistically significant differences between the means of two or more groups, statistical analyses including the analysis of variance (ANOVA) and means comparison (LSD test) were used to investigate this matter.

\section{Materials and methods}

\subsection{Studied factors and statistical design}

This study considered the effect of four independent variables including water quality, zeolite percentage, cement content and curing age on one dependent variable (compressive strength of concrete). For this, compressive strength of 168 groups (treatments) of concrete cube raised by different combination of three mixing water types (W1: tap water, W2: a mixture of tap water and briny groundwater with equal proportion, and W3: briny groundwater), four levels of substituting cement with zeolite in the concrete mix design (Z1: 0\%, Z2: $10 \%, Z 3: 20 \%$, and Z4: $30 \%)$, two cement contents (C1: 250 and C2: $350 \mathrm{~kg} \cdot \mathrm{m}^{-3}$ ) and seven curing ages (d1: 3, d2: 7, d3: 28, d4: 56, d5: 90, d6: 180 and 
d7: 365 days) were assessed. Since each treatment had three replications, 504 concrete specimens were constructed in total.

In the similar studies, the variation of dependent variable such as compressive strength affected by independent variables such as zeolite percentage, cement content, water quality, curing age, and so on was mostly expressed in terms of value or percentage. On the other hand, in the present study, four factors (including water quality, zeolite percentage, cement content and curing age) and 11 interactions between them including 6 two-way interactions, 4 three-way interactions as well as one four-way interaction were sources of variation of concrete compressive strength. As a result, in order to do better analysis of data, statistical tests including ANOVA (analysis of variance) and means comparison were used. A factorial ANOVA test is an analysis of variance test with more than one independent variable. The primary purpose of this test is to understand whether there is an interaction between the two or more independent variables and the dependent variable. Post hoc tests as means comparison test (like LSD test: least significant difference) are an integral part of ANOVA which explore the differences between means of multiple groups [12]. Therefore, this study was carried out as a four-factor factorial experiment based on completely randomized design. The statistical analyses were performed using IBM SPSS 22 [27] software package.

\subsection{Mixing water}

The briny groundwater was prepared from a tube well located about $15 \mathrm{~km}$ north of Agh-Ghlla city, $32 \mathrm{~km}$ north of Gorgan city (the capital of Golestan province) and $38 \mathrm{~km}$ east of the Caspian Sea. Some physical and chemical properties of studied waters were measured (Table 1) according to the methods of American public health association (APHA) [28]. It can be found that the bicarbonate $\left(\mathrm{HCO}_{3}{ }^{-}\right)$, chloride $\left(\mathrm{Cl}^{-}\right)$, sulphate $\left(\mathrm{SO}_{4}{ }^{2-}\right)$, calcium $\left(\mathrm{Ca}^{2+}\right)$, magnesium $\left(\mathrm{Mg}^{2+}\right)$, sodium $\left(\mathrm{Na}^{+}\right)$, potassium $\left(\mathrm{K}^{+}\right)$, total suspended solids (TDS), $\mathrm{pH}$, total hardness $(\mathrm{TH})$, total phosphorus $(\mathrm{P})$ and total nitrogen $(\mathrm{N})$ of briny groundwater were $3.5,1527,345,24.2,60.4,2091,1.75,258,0.96,46.8,0.40$, and 233.3 times that of tap water, respectively. Moreover, tap water was completely pure as to the total suspended solids (TSS), 5-days biological oxygen demands $\left(\mathrm{BOD}_{5}\right)$, and chemical oxygen demands (COD) while those measures in the briny groundwater were 8790, 2160 and $36670 \mathrm{ppm}$ (parts per million). So, the difference between tap water and briny groundwater specifications was proven especially in terms of total $\mathrm{Cl}^{-}, \mathrm{SO}_{4}{ }^{2}, \mathrm{Na}^{+}, \mathrm{EC}, \mathrm{TDS}$, total $\mathrm{N}, \mathrm{TSS}, \mathrm{BOD}_{5}$, and COD.

Specifications of concrete mixing water mainly were described in ASTM C1602 [3], ISO 12439 [5] and BS EN1008 [29]. Also, some national codes were presented by different countries. A comprehensive comparison between these codes was presented by Kaboosi et al. [12]. Comparison of the properties of the studied waters with permissible limits of contaminants in the mixing water of plain concrete based on the different standards showed that the tap water (W1) properties were within permissible ranges of different standards. However, there was a significant difference between the specification of combined water (W2) and briny groundwater (W3) with permissible limits of mixing water standards excluding specifications $\mathrm{pH}, \mathrm{K}^{+}$, total $\mathrm{P}$ and total $\mathrm{N}$. For instance, the concentration of $\mathrm{Cl}^{-}$in W2 and W3 was 103 and 205 times the limit of ASTM C1602 [3] and 23 and 46 times the limit of ISO 12439 [5], respectively. Therefore, it is expected in this study that the compressive strength of concrete samples made with the tap water be significantly more than both briny groundwater and combined water.

\subsection{Cementitious materials}

The study investigated the partially use of zeolite instead of cement in the concrete mix design. The clinoptilolite type of powdery zeolite was prepared from Semnan Negin Powder Company. The chemical properties of the zeolite (Table 2) showed that the minimum pozzolanic activity of used zeolite, which equals to the sum of $\mathrm{SiO}_{2}, \mathrm{Al}_{2} \mathrm{O}_{3}$ and ferric oxide $\left(\mathrm{Fe}_{2} \mathrm{O}_{3}\right)$, as well as its sulfur trioxide content $\left(\mathrm{SO}_{3}\right)$ were in accordance with the specifications of ASTM C618 [30]. The Portland cement of type II with anti-sulfate properties was prepared from Shahroud Cement Company. The chemical properties of cement are also presented in Table 2. 
Table 1: Chemical properties of different mixing waters (as ppm except for $\mathrm{pH}$ ).

\begin{tabular}{|c|c|c|c|c|c|c|c|c|}
\hline Property & Carbonate & Bicarbonate & Chloride & Sulfate & Calcium & Magnesium & Sodium & Potassium \\
\hline Tap Water & 0.0 & 396.6 & 134.7 & 115.3 & 58.1 & 58.4 & 59.8 & 4.0 \\
\hline Mixed Water & 0.0 & 899.9 & 102901.4 & 20230.2 & 730.5 & 1792.4 & 62532.4 & 5.5 \\
\hline $\begin{array}{c}\text { Briny } \\
\text { Groundwater }\end{array}$ & 0.0 & 1403.2 & 205668.0 & 40345.2 & 1402.8 & 3526.4 & 125005.0 & 7.0 \\
\hline Property & TDS & $\mathrm{pH}$ & TH & Total P & Total N & BOD $_{5}$ & COD & TSS \\
\hline Tap Water & 806 & 7.6 & 385 & 0.5 & 1.2 & 0 & 0 & 0 \\
\hline Mixed Water & 104403 & 7.5 & 9193 & 0.4 & 140.6 & 1080 & 18335 & 4395 \\
\hline $\begin{array}{c}\text { Briny } \\
\text { Groundwater }\end{array}$ & 208001 & 7.3 & 18000 & 0.2 & 280 & 2160 & 36670 & 8790 \\
\hline
\end{tabular}

TDS: Total Dissolved Solids; TH: Total Hardness; BOD 5 : 5-days Biological Oxygen Demands; COD: Chemical Oxygen Demands; TSS: Total Suspended Solids

Table 2: Chemical composition of cement and zeolite (percent).

\begin{tabular}{|c|c|c|c|c|c|c|c|c|}
\hline Composition & Cement & Zeolite & Composition & Cement & Zeolite & Composition & Cement & Zeolite \\
\hline $\mathrm{SiO}_{2}$ & 21.11 & 69.28 & $\mathrm{CaO}$ & 63.36 & 3.56 & $\mathrm{MgO}$ & 1.51 & 0.50 \\
\hline $\mathrm{Al}_{2} \mathrm{O}_{3}$ & 4.42 & 10.43 & $\mathrm{Na}_{2} \mathrm{O}$ & 0.38 & 0.73 & $\mathrm{SO}_{3}$ & 2.61 & 0.005 \\
\hline $\mathrm{Fe}_{2} \mathrm{O}_{3}$ & 3.96 & 0.49 & $\mathrm{~K}_{2} \mathrm{O}$ & 0.51 & 1.27 & $\mathrm{LOI}$ & 2.98 & 12.97 \\
\hline
\end{tabular}

\subsection{Other admixtures and concrete mix design}

Other admixtures of concrete and procedure of experiment in the present study were in accordance with Kaboosi et al. [12]. Some materials and equipment are shown in Fig. 1. The double washed fine and coarse aggregates with the specific gravity 2550 and $2620 \mathrm{~kg} \cdot \mathrm{m}^{-3}$ were used to produce concrete, respectively. The results of the aggregates grading test based on ASTM C136/C136M [31] showed that fine aggregate fineness modulus was 2.9; whereas the maximum size of fine and coarse aggregates were 9.5 and $19 \mathrm{~mm}$, respectively. Therefore, the requirements of ASTM C33/C33M [32] were met.

Totally 558 cubic concrete samples with dimension $150 \times 150 \times 150 \mathrm{~mm}$ were made including 54 samples for selecting the mix design as well as 504 samples for the main experiment. Concrete compaction and sampling were based on ASTM C192/C192M [33] and ISO 1920-1 [34], respectively. In order to select the suitable mix design, 18 different mix designs with three replications including three ratios of fine to coarse aggregates; two ratios of water to cementitious materials; and three concrete specific gravity values were tested and final mix design (ratio of water to cementitious materials 0.45 , fine to coarse aggregates ratio $1: 1$ and concrete specific gravity of $2400 \mathrm{~kg} \cdot \mathrm{m}^{-3}$ ) was selected based on the maximum 3-days compressive strength.

The curing procedure of samples was started after 24 hours of their construction in the three separate curing tanks $(1 \times 1 \times 1$ meters $)$. Each tank was filled with the same water used for making the concrete. Measuring the compressive strength of concrete samples based on the provisions of ISO 1920-4 [35] was conducted by ELE International- ADR- Auto 3000- compression machine
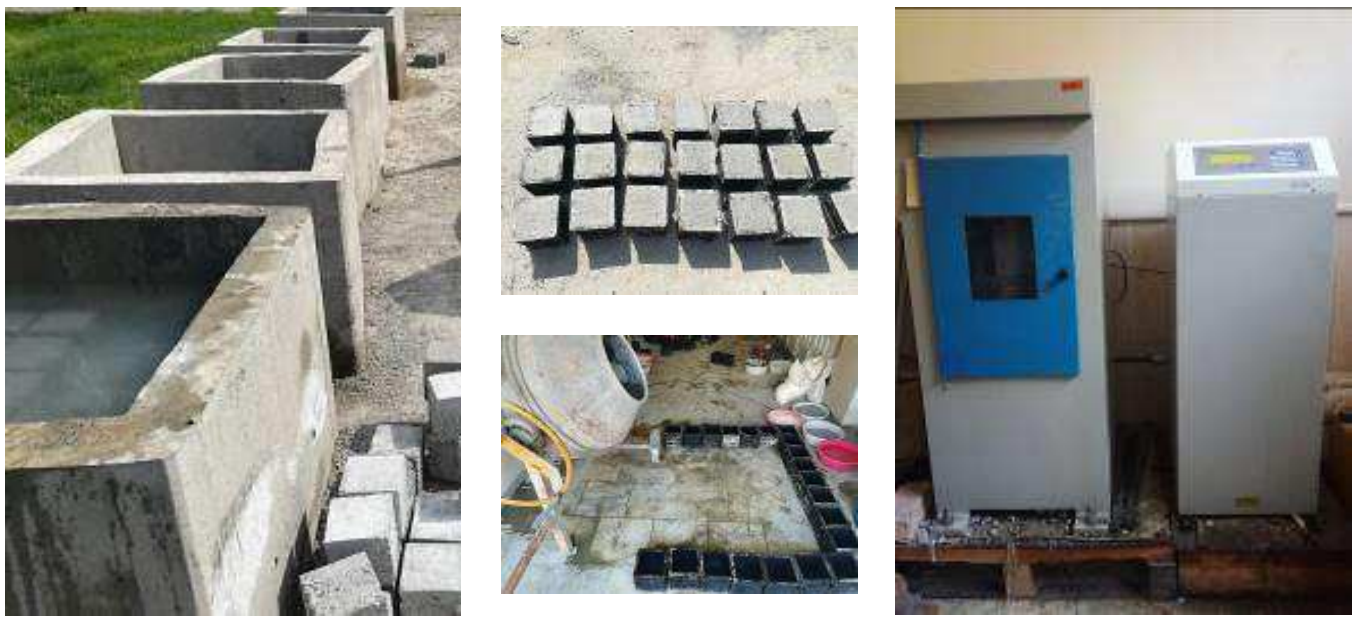

Fig. 1: A view of curing tanks, concrete materials and compression machine. 


\section{Results and discussion}

The results of the analysis of variance (Table 3 ) showed that the simple effects of cement content, water type, zeolite percentage and curing age and all two-way interactions except the water type $\times$ curing age and zeolite percentage $\times$ curing age as well as a three-way interactions of cement content $\times$ water type $\times$ zeolite percentage on the concrete compressive strength were statistically significant $(P$ Value $\leq 0.01)$. Also, four-way interaction of cement content $\times$ water type $\times$ zeolite level $\times$ curing age in the compressive strength of concrete was not statistically significant. The above results are very similar to the findings of Kaboosi et al. [12] and Kaboosi and Emami [25]. The significant twoway interactions of water type $\times$ curing age and zeolite percentage $\times$ curing age indicated that the effect of water type and zeolite percentage in the concrete compressive strength at different curing ages were similar, respectively. This means that the variation rate of concrete compressive strength by time was not affected by the type of mixing water and the use of zeolite percentage, respectively. Also, insignificant three-way interactions of cement content $\times$ water type $\times$ curing age, cement content $x$ zeolite percentage $\times$ curing age and water type $\times$ zeolite percentage $\times$ curing age demonstrated that the dependency of concrete compressive strength on the time (curing age) was similar in different combinations of the cement content and water type, cement content and zeolite percentage, and water type and zeolite percentage, respectively. Similarly, insignificant four-way interaction of cement content $\times$ water type $\times$ zeolite level $\times$ curing age indicated that the variation of concrete compressive strength by time (curing age) in different combinations of cement content, water type and zeolite percentage in the concrete mix designs was similar. It is necessary to mention that four studied factors (including water quality, zeolite percentage, cement content and curing age) and 11 situations of interactions between them (including 6 two-way interactions, 4 three-way interactions as well as one four-way interaction) were sources of variation of concrete compressive strength in the present study. Since some interactions were not statistically significant (Table 3), the means comparison results (based on LSD test) are presented only for the sources of variation (situations) which had significant effects in the concrete compressive strength. Therefore, the results of the effect of four studied factors in the concrete compressive strength (Fig. 2), as well as four two-way interactions (Table 4) and one three-way interaction (Fig. 3) are presented following. Accordingly, the means comparison results of two two-way interactions, three three-way interactions as well as one four-way interaction will not be discussed in the following because of their insignificant interactions. Statistical insignificance of each interaction means the simultaneous effect of its factors in concrete compressive strength is similar to the separate effects of the included factors.

It is necessary to mention that regarding the two- and three-way significant interactions of the studied factors in most cases (Table 3), the more attention should be paid to the results of the interactions than simple effects of studied factors because the study of means comparison of simple effects (Fig. 2) cannot direct us to a proper conclusion. It should be considered that in the results of means comparison for each situation, the treatments which have at least one similar lowercase or uppercase sign (letter) did not have a significant difference at $5 \%$ statistical level based on the LSD test.

Table 3: The results of analysis of varience (ANOVA) test on compressive strength of concrete.

\begin{tabular}{|c|c|c|c|}
\hline Source of variation & Degree of freedom & Mean square & Sig. \\
\hline Cement Content $(\mathrm{C})$ & 1 & 42707.89 & 0.000 \\
\hline Water Type $(\mathrm{W})$ & 2 & 236.85 & 0.000 \\
\hline Zeolite Percentage $(\mathrm{Z})$ & 3 & 646.45 & 0.000 \\
\hline Curing Time $(\mathrm{d})$ & 6 & 1404.60 & 0.000 \\
\hline Interaction of $\mathrm{C} \times \mathrm{W}$ & 2 & 183.78 & 0.000 \\
\hline Interaction of $\mathrm{C} \times \mathrm{Z}$ & 3 & 235.50 & 0.000 \\
\hline Interaction of $\mathrm{C} \times \mathrm{d}$ & 6 & 184.62 & 0.000 \\
\hline Interaction of $\mathrm{W} \times \mathrm{Z}$ & 6 & 92.64 & 0.000 \\
\hline Interaction of $\mathrm{W} \times \mathrm{d}$ & 12 & 8.68 & 0.311 \\
\hline Interaction of $\mathrm{Z} \times \mathrm{d}$ & 18 & 6.74 & 0.579 \\
\hline Interaction of $\mathrm{C} \times \mathrm{W} \times \mathrm{Z}$ & 6 & 139.41 & 0.000 \\
\hline Interaction of $\mathrm{C} \times \mathrm{W} \times \mathrm{d}$ & 12 & 8.38 & 0.343 \\
\hline
\end{tabular}




\begin{tabular}{|c|c|c|c|}
\hline Interaction of $\mathrm{C} \times \mathrm{Z} \times \mathrm{d}$ & 18 & 11.39 & 0.186 \\
\hline Interaction of $\mathrm{W} \times \mathrm{Z} \times \mathrm{d}$ & 36 & 4.19 & 0.384 \\
\hline Interaction of $\mathrm{W} \times \mathrm{Z} \times \mathrm{C} \times \mathrm{d}$ & 36 & 9.95 & 0.105 \\
\hline Total error & 336 & 7.49 & - \\
\hline
\end{tabular}

\subsection{Means comparison of simple effects}

The results of means comparison of simple effects of four investigated factors in compressive strength of concrete are presented in Fig. 2. As expected, increasing the cement content from 250 to $350 \mathrm{~kg} \cdot \mathrm{m}^{-3}$ resulted in a significant increase in concrete compressive strength (147 \% on average). Also, the significant increase of compressive strength for each curing age compared with the aforetime curing age was seen (Fig. 2). The rates of these increas were $16.4 \%, 18.6 \%, 8.6 \%, 6 \%, 6.3 \%$ and $9.2 \%$ in curing ages 7 to 365 days, respectively.

The obtained results showed that although the utilizing combined water (W2) as mixing water significantly decreased the concrete compressive strength compared with the tap water (W1) by $8.0 \%$, this reduction was placed within the allowable limit lower than $10 \%$ based on standards of ISO 12439 [5] and MPO [6]. Also, the positive variation (2.3\%) in the briny groundwater treatment (W3) was seen that was not statistically significant (Fig. 2). Therefore, it seems that the use of briny groundwater and combined water did not have destructive effect on compressive strength of plain concrete. It was reported that the compressive strength of concrete made with highly saline water was increased by $4.2 \%$ compared with freshwater [10]. Also, compared with freshwater, the use of saline wastewater discharged from the seawater treatment plant with a high concentration of calcium, magnesium, and chloride did not result in a significant reduction of concrete compressive strength [2]. These findings are closely in accordance with the results of the present study and also can be verified by results of Alqam et al. [36]. They showed that the compressive strength of concrete made with the unconventional mixing water containing 140 ppm (range 85 - 213), 100 ppm (range 88 - 145), 640 ppm (range $420-750$ ) of TSS, $\mathrm{BOD}_{5}$, and $\mathrm{COD}$ was greater than one that made with freshwater. Therefore, it seems that allowable limit of these impurities of the mixing water presented by EPA [37] $(30,30$, and $500 \mathrm{ppm}$, respectively) are very cautiously and those require to a revision. The mixing water contaminants have various effects on concrete, but possibly not all of them have destructive effects; therefore, some of them can be harmless and even can improve the properties of concrete. In most cases, there are virtual limits for the amount of impurities in concrete mixing water, while some impurities can be harmless [38-39]. This may be the reason for the negligible variation of compressive strength of the concrete made with both unconventional waters compared with the tap water.

Averagely, the usage of all percentages of zeolite resulted in a significant reduction of concrete compressive strength compared to non-zeolite treatment. Meanwhile, the difference between zeolite levels 10 and 20 percent was not significant. The reduction of concrete compressive strength compared with the non-zeolite condition was 10.2, 10.5 and 22.7 percent for the zeolite levels of 10, 20 and 30 percent, respectively (Fig. 2). These results were in accordance with the findings of Madandoust et al. [13], Najimi et al. [14] and Vejmelková et al., [15]. Madandoust et al. [13] showed that the substitution of cement with natural zeolite by $20 \%$ reduced the 3 - up to 90 -days compressive strength of concrete by 5 - 17 percent. Najimi et al. [14] also found that substitution of 15 and 30 percent of cement with zeolite resulted in the reduction of compressive strength at all curing ages ( 7 , 14, 28, 90 and 356 days) by 3 - 15 and 7 - 38 percent, respectively. Furthermore, Vejmelková et al., [15] reported that application of 10,20 and 40 percent of zeolite led to the reduction of the 7-, 28- and 360-days compressive strength of high-performance concrete by $4-18,25$ - 35 and $45-63$ percent, respectively. 


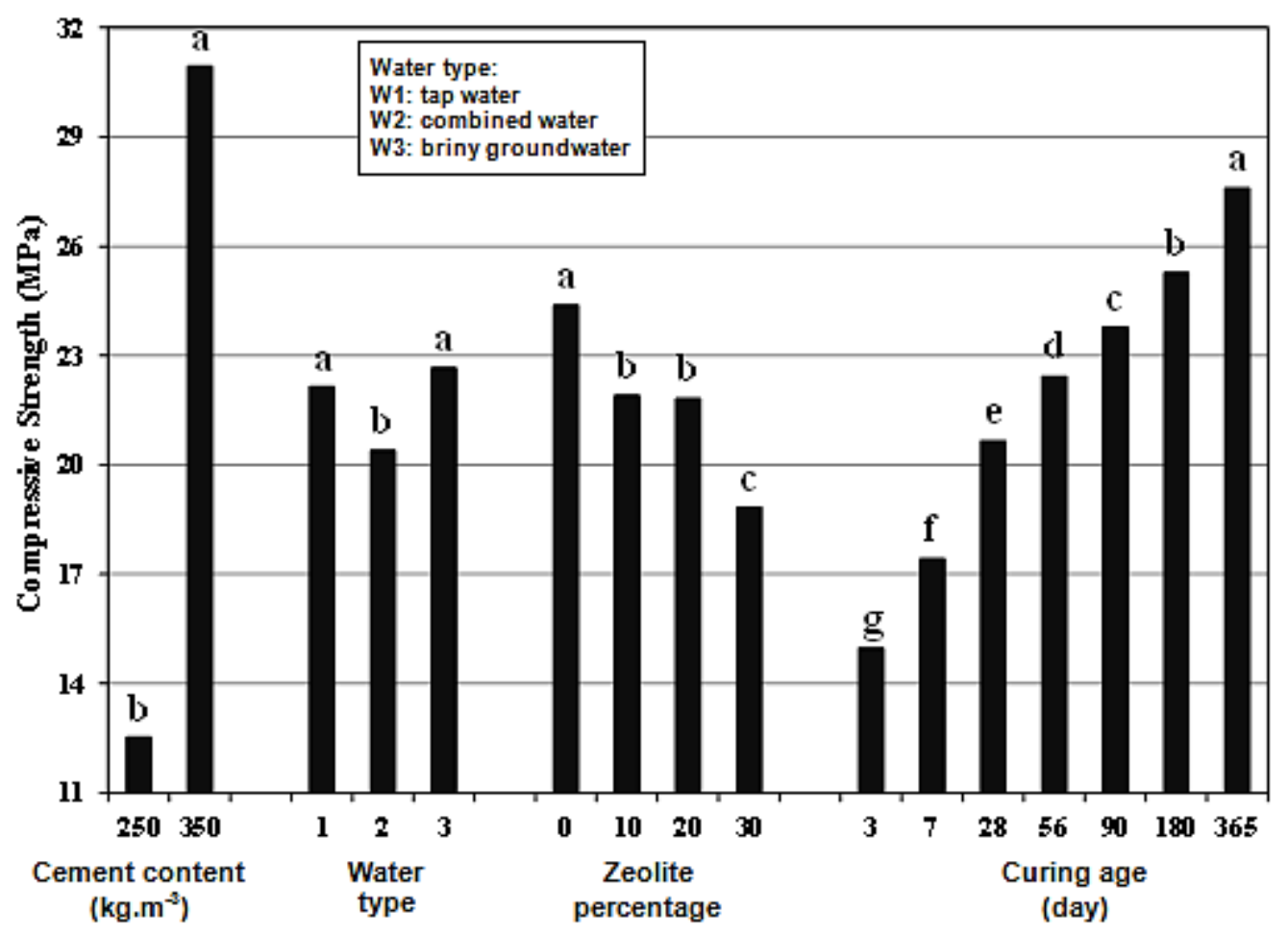

Fig. 2: The simple effect of studied factors in the compressive strength of concrete. Note: For each factor, the treatments which have at least one similar letter did not have significant difference at $5 \%$ statistical level based on the LSD test.

\subsection{Means comparison of two-way interactions}

The means comparison of two-way interactions of cement content $\times$ water type, cement content $\times$ zeolite percentage, cement content $\times$ curing age and water type $\times$ zeolite percentage are presented in Table (4). The results of two-way interaction of cement content $\times$ water type (Table 4.a) indicates that in the cement content $250 \mathrm{~kg} \cdot \mathrm{m}^{-3}$, the compressive strength of specimens made with combined water (W2) did not have significant difference with ones that made with the tap water (W1), while the use of briny groundwater (W3) resulted in a significant increase $(20.2 \%)$ in the compressive strength of specimens compared with the tap water and the combined water. This finding is soundly in accordance with the results of Shi et al. [8]. They found that the use of seawater as mixing water of concrete increased the 28-days compressive strength of concrete compared with tap water by $22 \%$. It was reported that acceleration of cement hydration by $\mathrm{CaCl}_{2}$ of seawater resulted in the increase of $\mathrm{CH}$ (calcium hydroxide) content of cement, a decrease in the voids bigger than $10 \mathrm{~nm}$ (nano-meter), the improvement of the pore structure and microstructure of concrete and finally the increase in the compressive strength of concrete [8]. On the contrary, in the cement content $350 \mathrm{~kg} \cdot \mathrm{m}^{-3}$, the compressive strength of specimens made with combined water and briny groundwater compared with the tap water significantly reduced by 10.8 and 4.2 percent, respectively. This was in accordance with the results of Mbadike and Elinwa [9]. They showed that the compressive strength of concrete due to the use of seawater instead of tap water reduced by $2 \%-10 \%$ in different water to cement ratios. However, in this cement content, the reduction of concrete compressive strength due to using both unconventional water nearly was placed within the allowable limit lower than $10 \%$ based on ISO 12439 [5], MPO [6]. Therefore, it seems that using the briny groundwater and combined water as mixing water can be recommendable in both cement contents. There is very little data about the simultaneous effects of using unconventional water and cement content on the compressive strength of concrete. So, it is necessary to conduct further research in this subject. It should be mentioned that considering the interaction of cement content $\times$ water type $\times$ zeolite level (Table 3 ), the zeolite percentage had a considerable effect on the final conclusion in this regard. This matter is discussed in section 3.3 (three-way interaction). However, since the interaction of cement content $\times$ water type $\times$ curing age was not significant (Table 3 ), it can be found that this reaction was not affected by the factor of curing age. It means that the effect of curing age on compressive strength of concrete was similar in each possible combination of cement content and water type and its value was equal to the 
simple effect of curing age on compressive strength of concrete according to Fig. 2.

The means comparison of two-way interaction of cement content $\times$ zeolite level (Table 4b) indicates that in the cement content $250 \mathrm{~kg} \cdot \mathrm{m}^{-3}$, the use of zeolite in different percentages significantly reduced the compressive strength of concrete compared to the non-zeolite content, though the difference of zeolite levels $10 \%$ and $20 \%$ was not significant. However, in the cement content 350 $\mathrm{kg} \cdot \mathrm{m}^{-3}$, application of zeolite up to $20 \%$ resulted in no significant reduction in the concrete compressive strength compared with the non-zeolite treatment while the use of $30 \%$ zeolite significantly reduced this property. Also, the variation rates of compressive strength of specimens made with the zeolite compared to the non-zeolite in the cement content $350 \mathrm{~kg} \cdot \mathrm{m}^{-3}$ were less than $250 \mathrm{~kg} \cdot \mathrm{m}^{-3}$; so that, compared with non-use of zeolite, the use of zeolite in the cement content 250 $\mathrm{kg} \cdot \mathrm{m}^{-3}$ decreased the compressive strength of concrete by 32.5, 29.9 and 45.4 percent while in the cement content $350 \mathrm{~kg} \cdot \mathrm{m}^{-3}$, it was changed by $+2.0,0.0$ and -10.4 percent, respectively. Therefore, it seems that the use of zeolite at the optimum proportion up to $20 \%$ in the concrete with the high cement content was not faced with serious restriction in term of compressive strength. It was reported that due to the variety of natural zeolites in terms of structure, chemical composition, reactivity and purity, the effect of substitution of cement with zeolite in compressive strength of concrete was different [14]. However, as it was mentioned, considering the significant interaction of cement content $\times$ water type $\times$ zeolite level (Table 3 ), reaction of water type with each possible combination of cement content and zeolite percentage should be considered for the final conclusion in this regard. Similarly, since the interaction of cement content $\times$ zeolite level $\times$ curing age was not significant (Table 3 ), it can be found that the effect of curing age on compressive strength of concrete in each possible combination of cement content and zeolite percentage was not different.

The significant interaction of cement content $\times$ curing age (Table 3 ) was due to the different rates of increase of concrete compressive strength by curing time in the various cement contents. The means comparison of two-way interaction of cement content $\times$ curing age (Table 4.c) shows that the increase rate of compressive strength of concrete was different in two cement contents; so that this property in the cement content $250 \mathrm{~kg} \cdot \mathrm{m}^{-3}$ at curing ages $7,28,56,90,180$ and 365 days compared with the curing age 3 days was $16.1,34.9,44.2,57.9,70.4$ and 109.8 percent, while in the cement content $350 \mathrm{~kg} \cdot \mathrm{m}^{-3}$ it was $16.5,39.3,52.1,59.2,68.2$ and 74.3 percent, respectively. Therefore, during young curing ages, the increase rate of concrete compressive strength in the cement content 350 $\mathrm{kg} \cdot \mathrm{m}^{-3}$ was greater than the cement content $250 \mathrm{~kg} \cdot \mathrm{m}^{-3}$ while this trend was completely adverse during old curing ages (180 and 365 days). Also, regarding the insignificant interactions of cement content $x$ water type $\times$ curing age and cement content $\times$ zeolite level $\times$ curing age (Table 3 ), these rates were statistically similar in different combinations of cement content and water type as well as in different combinations of cement content and zeolite percentage.

Means comparison of two-way interaction of water type $\times$ zeolite percentage (Table 4d) indicates that the greatest value of compressive strength was obtained in the briny groundwater without zeolite content treatment that its superiority compared with the other treatments was statistically significant. On the other hand, the lowest value of compressive strength of concrete was obtained in the treatments of zeolite $30 \%$ with tap water as well as zeolite $30 \%$ with briny groundwater that had the significant difference compared to the other treatments. Moreover, the results showed that the lowest variation in the compressive strength of concrete due to the usage of zeolite occurred in the combined water treatments so that this property was not significantly affected by the different percentages of zeolite when combined water was used as mixing water. This variation was $8.4 \%-23.9 \%, 3.0 \%-8.0 \%$ and $16.4 \%-32.8 \%$ for tap water, combined water and briny groundwater, respectively. However, compared with the control treatment (tap water without zeolite content), the reduction of compressive strength of concrete affected by the simultaneous use of zeolite up to $20 \%$ with tap water or briny groundwater was not greater than $10 \%$. Similarly, it was reported that substituting cement by zeolite up to $20 \%$ did not cause the reduction of compressive strength of concrete $[19,24]$ which is closely in accordance with the results of present study. Since there is little data about the simultaneous effects of using unconventional water and zeolite percentage on the compressive strength of concrete, it is necessary to conduct similar studies to achieve a proper conclusion in this subject. Also, as it was previously mentioned, the interaction of these two factors (water type and zeolite percentage) in the compressive strength of concrete was affected by cement content but was not affected by curing age (Table 3). Therefore, three-way interaction of cement content $\times$ zeolite percentage $\times$ water type should be considered for achieving the final conclusion in this regard. These are analyzed in section 3.3. 
Table 4: Means comparison of two-way interactions on compressive strength (CS) of concrete (MPa).

\begin{tabular}{|c|c|c|c|c|c|}
\hline \multicolumn{3}{|c|}{ A: Interaction of cement content $\times$ water type } & \multicolumn{3}{|c|}{ B: Interaction of cement content $\times$ zeolite percentage } \\
\hline Cement content & Water Type & CS & Cement content & Zeolite percentage & CS \\
\hline \multirow{3}{*}{$250 \mathrm{~kg} \cdot \mathrm{m}^{-3}$} & Tap water & $11.73 \mathrm{e}$ & \multirow{4}{*}{$250 \mathrm{~kg} \cdot \mathrm{m}^{-3}$} & 0 & $17.15 \mathrm{c}$ \\
\hline & Combined water & $11.75 \mathrm{e}$ & & 10 & $11.58 \mathrm{~d}$ \\
\hline & Briny groundwater & $14.10 \mathrm{~d}$ & & 20 & $12.02 \mathrm{~d}$ \\
\hline \multirow{3}{*}{$350 \mathrm{~kg} \cdot \mathrm{m}^{-3}$} & Tap water & $32.56 \mathrm{a}$ & & 30 & $9.36 \mathrm{e}$ \\
\hline & Combined water & 29.05 c & \multirow{4}{*}{$350 \mathrm{~kg} \cdot \mathrm{m}^{-3}$} & 0 & $31.60 \mathrm{a}$ \\
\hline & Briny groundwater & $31.20 \mathrm{~b}$ & & 10 & $32.22 \mathrm{a}$ \\
\hline \multicolumn{3}{|c|}{ C: Interaction of cement content $\times$ curing age } & & 20 & $31.61 \mathrm{a}$ \\
\hline Cement content & Curing age (day) & CS & & 30 & $28.32 \mathrm{~b}$ \\
\hline \multirow{7}{*}{$250 \mathrm{~kg} \cdot \mathrm{m}^{-3}$} & 3 & $8.49 \mathrm{~m}$ & D: Interaction & water type $\times$ zeolite & entage \\
\hline & 7 & 9.851 & Water type & Zeolite percentage & CS \\
\hline & 28 & $11.45 \mathrm{k}$ & \multirow{4}{*}{ Tap water } & 0 & $24.74 \mathrm{~b}$ \\
\hline & 56 & $12.23 \mathrm{jk}$ & & 10 & $22.38 \mathrm{~cd}$ \\
\hline & 90 & $13.4 \mathrm{ij}$ & & 20 & $22.66 \mathrm{c}$ \\
\hline & 180 & $14.46 \mathrm{i}$ & & 30 & $18.82 \mathrm{gh}$ \\
\hline & 365 & $17.8 \mathrm{~h}$ & \multirow{4}{*}{ Combined water } & 0 & $21.29 \mathrm{de}$ \\
\hline \multirow{7}{*}{$350 \mathrm{~kg} \cdot \mathrm{m}^{-3}$} & 3 & $21.45 \mathrm{~g}$ & & 10 & 20.65 ef \\
\hline & 7 & $24.99 \mathrm{f}$ & & 20 & 20.12 ef \\
\hline & 28 & 29.87 e & & 30 & $19.50 \mathrm{fg}$ \\
\hline & 56 & $32.63 d$ & \multirow{4}{*}{ Briny groundwater } & 0 & $27.09 \mathrm{a}$ \\
\hline & 90 & $34.15 \mathrm{c}$ & & 10 & $22.66 \mathrm{c}$ \\
\hline & 180 & $36.08 \mathrm{~b}$ & & 20 & $22.65 \mathrm{c}$ \\
\hline & 365 & $37.38 \mathrm{a}$ & & 30 & $18.2 \mathrm{~h}$ \\
\hline
\end{tabular}

Note: For each interaction, the treatments which have at least one similar letter did not have significant difference at $5 \%$ statistical level based on the LSD test.

\subsection{Means comparison of three-way interaction}

The means comparison of three-way interaction of cement content $\times$ zeolite percentage $\times$ water type is presented in Fig. 3. The results showed that in the cement content $250 \mathrm{~kg} \cdot \mathrm{m}^{-3}$, the use of the briny groundwater with non-zeolite content (C1Z1W3) significantly increased the concrete compressive strength compared with the control treatment (C1Z1W1: non-zeolite with tap water) by $22.0 \%$ while other combinations of these three factors resulted in a significant reduction (between $22.0 \%$ to $56.9 \%$ ) of this property. However, in this cement content, there was not a significant negative difference between different combinations of unconventional waters and zeolite usage. On the other hand, in the cement content $350 \mathrm{~kg} \cdot \mathrm{m}^{-3}$, the significant increase of compressive strength of concrete was observed in the treatments of zeolite $10 \%$ with tap water (C2Z2W1) and zeolite $20 \%$ with tap water (C2Z3W1) and zeolite $20 \%$ with briny groudwater (C2Z3W3) compared to the control treatment (C2Z1W1: non-zeolite content with tap water) by $5.5 \%, 6.6 \%$ and $5.9 \%$, respectively. Furthermore, for this cement content, the decrease of compressive strength of concrete compared with the control treatment was only statistically significant in the treatments of non-zeolite with combined water (C2Z1W2) and zeolite $20 \%$ with combined water (C2Z3W2) and zeolite $30 \%$ with the all waters (C2Z4W1, C2Z4W2 and C2Z4W3). So, the variation (increase/decrease) of concrete compressive strength in other treatments (between $-4.6 \%$ to $+2.7 \%$ ) was not statistically significant. These findings show that in this cement content, the simultaneous use of unconventional salty water as mixing water with zeolite up to $20 \%$ as a pozzolanic additive in the concrete mix design generally had a positive effect on the compressive strength of concrete. Therefore, it can be concluded that simultaneous use of unconventional water with zeolite up to $20 \%$ had a more efficiency in the cement content $350 \mathrm{~kg} \cdot \mathrm{m}^{-3}$ than $250 \mathrm{~kg} \cdot \mathrm{m}^{-3}$ in term of compressive strength of concrete. Therefore, the use of these materials can be recommendable for construction of concrete in the high cement content. These results were in accordance with the findings of Wegian [7], Kaboosi et al. [12] and Kaboosi and Emami 
[25]. Wegian [7] reported that resistance against all possible forms of deterioration is distinctly improved by using higher cement contents. Increasing the cement content due to more cement matrix exposed to salts, better workability to the mix, enhancement of the bond strength among concrete components and retarding the strength loss lead to the construction of concrete with higher resistance to the attack of chemical solutions and salts [7].

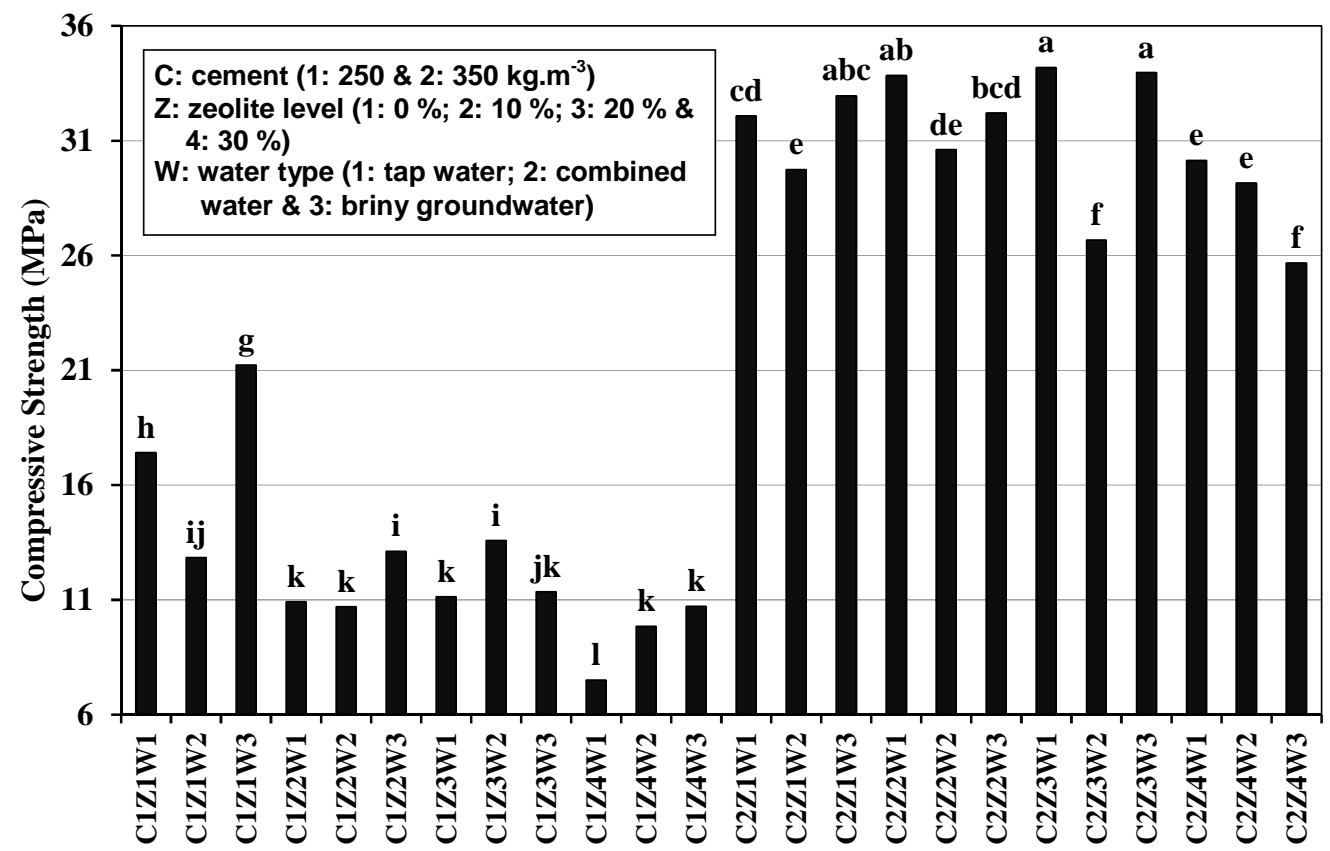

Fig. 3: The means comparison result of three-way interaction of cement content $\times$ zeolite percentage $x$ water type on compressive strength of concrete. Note: Treatments with at least one similar letter did not show a significant difference at $5 \%$ statistical level based on LSD.

\section{Conclusion}

The present study investigated the simple effects and interactions of four factors including briny groundwater, percentage of zeolite, cement content and curing age on the compressive strength of concrete by statistical analysis. The results of the simple effect of studied factors showed that the use of briny groundwater and combined water compared with the tap water resulted in an insignificant increase and a significant decrease in the compressive strength of concrete, respectively. However, since the variation was within the permissible range $10 \%$ according to different mixing water standards, the use of these unconventional waters can be permitted. Also, although cement substitution with the zeolite in the different percentages compared with the non-zeolite content significantly reduced the compressive strength of concrete, the difference between substitution 10 and 20 was not statistically significant. The results showed that the three-way interaction of cement content $\times$ water type $\times$ zeolite percentage on compressive strength of concrete was statistically significant which signifies different effects of cement content in the various combinations of water type and zeolite percentage. Therefore, optimum zeolite percentage and water type should be selected based on the cement content by performing an in-situ mix design test. As a recommendation, the simultaneous use of both two types of unconventional water with zeolite up to $20 \%$ in the high cement content (350 $\mathrm{kg} \cdot \mathrm{m}^{-3}$ ) can be proposed for plain concrete in terms of compressive strength.

\section{References}

[1] MILLER, S.A. - HORVATH, A. - MONTEIRO, P.J.M.: Impacts of booming concrete production on water resources worldwide. Nature Sustainability, Vol. 1, 2018, pp. 69-76.

[2] FATTAH, K.P. - AL-TAMIMI, A.K. - HAMWEYAH, W. - IQBAL, F.: Evaluation of sustainable concrete produced with desalinated reject brine. International Journal of Sustainable Built Environment, Vol. 6, 2017, pp. 183-190.

[3] ASTM C1602. 2012 Standard specification for mixing water used in the production of hydraulic 
cement concrete, ASTM International, West Conshohocken, PA, www.astm.org

[4] BABU, G.R. - RAMANA, N.V.: Feasibility of wastewater as mixing water in cement. Materials Today, Proceedings, Vol. 5, 2018, pp. 1607-1614.

[5] ISO 12439, 2010. Mixing water for concrete. International Organization for Standardization, Geneva, Switzerland (Last update: 2015).

[6] MPO, 2004. Concrete code of Iran. Management and Planning Organization of Iran, Publication No. 120.

[7] WEGIAN, F.M.: Effect of seawater for mixing and curing on structural concrete. The IES Journal Part A: Civil \& Structural Engineering, Vol. 3 (4), 2010, pp. 235-243.

[8] SHI, Z. - SHUI, Z. - LI, Q. - GENG, H.: Combined effect of metakaolin and sea water on performance and microstructures of concrete. Construction and Building Materials, Vol. 74, 2015, pp. 57-64.

[9] MBADIKE, E.M. - ELINWA, A.U.: Effect of salt water in the production of concrete. Nigerian Journal of Technology, Vol. 30 (2), 2011, pp. 105-110.

[10] AL-JOULANI, N.M.A.: Effect of wastewater type on concrete properties. International Journal of Applied Engineering Research, Vol. 10 (19), 2015, pp. 39865-39870.

[11] EL-NAWAWY, O.A. - AHMAD, S.: Use of treated effluent in concrete mixing in an arid climate. Cement and Concrete Composites, Vol. 13, 1991, pp. 137-141.

[12] KABOOSI, K. - KABOOSI, F. - FADAVI, M.: Investigation of greywater and zeolite usage in different cement contents on concrete compressive strength and their interactions. Ain Shams Engineering Journal, 2019, https://doi.org/10.1016/j.asej.2019.08.008.

[13] MADANDOUST, R. - SOBHANI, J. - ASHOORI, P.: Concrete made with zeolite and metakaolin: a comparison on the strength and durability properties. Asian Journal of Civil Engineering (BHRC), Vol. 14 (4), 2013, pp. 533-543.

[14] NAJIMI, M. - SOBHANI, J. - AHMADI, B. - SHEKARCHI, M.: An experimental study on durability properties of concrete containing zeolite as a highly reactive natural pozzolan. Construction and Building Materials, Vol. 35, 2012, pp.1023-1033.

[15] VEJMELKOVÁ, E. - ONDRÁČEK, M. - ČERNÝ, R.: Mechanical and hydric properties of high performance concrete containing natural zeolites. International Journal of Materials and Metallurgical Engineering, Vol. 6 (3), 2012, pp. 186-189.

[16] SOLTANI, A. - TARIGHAT, A. - ROSTAMI, R.: Effects of calcined clay minerals and silica fume on the compressive strength of concrete (In Persian). Journal of Structural and Construction Engineering, Vol. 4 (1), 2017, pp. 33-50.

[17] RANJBAR, M. - MADANDOUST, R. - MOUSAVI, S.: Combined effect of silica fume and zeolite on the fresh and hardened properties of self-compacted concrete (In Persian). Concrete Research, Vol. 6 (1), 2013, pp. 53-71.

[18] VALIPOUR, M. - PARGAR, F. - SHEKARCHI, M. - KHANI, S.: Comparing a natural pozzolan, zeolite, to metakaolin and silica fume in terms of their effect on the durability characteristics of concrete: A laboratory study. Construction and Building Materials, Vol. 41, 2013, pp. 879-888.

[19] ESMAEILNIA OMRAN, M. - FARIDI, M.: Relationship between compressive strength and tensile strength, and modulus of elasticity in self-compacting concrete containing recycled aggregates and natural zeolite (In Persian). Concrete Research, Vol. 7 (1), 2015, pp. 7-22.

[20] [20] TRAN, Y.T. - LEE, J. - KUMAR, P. - KIM, K.H. - LEE, S.S.: Natural zeolite and its application in concrete composite production. Composites Part B, Vol. 165, 2019, pp. 354-364.

[21] VALIPOUR, M. - YEKKALAR, M. - SHEKARCHI, M. - PANAHI, S.: Environmental assessment of green concrete containing natural zeolite on the global warming index in marine environments. Journal of Cleaner Production, Vol. 65, 2014, pp. 418-423.

[22] SABET, F.A. - LIBRE, N.A. - SHEKARCHI, M.: Mechanical and durability properties of selfconsolidating high performance concrete incorporating natural zeolite, silica fume and fly ash. Construction and Building Materials, Vol. 44, 2013, pp. 175-184.

[23] AHMADI, J. - AZIZI, H. - KOOHI, M.: Effect of zeolite on the strength and permeability of conventional concrete with different content of cement. Concrete Research, 8(2), 2016, p. 5-18.

[24] KHOSHROO, M. - SHIRZADI JAVID, A.A. - KATEBI, A.: Effects of micro-nano bubble water and binary mineral admixtures on the mechanical and durability properties of concrete. Construction and Building Materials, Vol. 164, 2018, pp. 371-385.

[25] KABOOSI, K. - EMAMI, Kh.: Interaction of treated industrial wastewater and zeolite on compressive strength of plain concrete in different cement contents and curing ages. Case Studies in Construction Materials (accepted paper, under publishing), 2019.

[26] VEJMELKOVÁ, E. - KOŇÁKOVÁ, D. - KULOVANÁ, T. - KEPPERT, M. - ŽUMÁR, J. ROVNANÍKOVÁ, P. - KERŠNER, Z. - SEDLMAJER, M. - ČERNÝ, R.: Engineering properties of 
concrete containing natural zeolite as supplementary cementitious material. Strength, toughness, durability, and hygrothermal performance. Cement and Concrete Composites, Vol. 55, 2015, pp. 259-267.

[27] IBM Corp. 2016. IBM SPSS Statistics for Windows, Version 22.0. Armonk, NY: IBM Corp. (Released 2016).

[28] APHA. 2012 Standard methods for examination of water and wastewater. American Public Health Association, $18^{\text {th }}$ Edition, Washington DC.

[29] BS EN1008, 2002. Mixing water for concrete: Specification for sampling, testing and assessing the suitability of water, including water recovered from processes in the concrete industry, as mixing water for concrete. British Standard Institution, www.bsigroup.com.

[30] ASTM C618-19, 2019. Standard Specification for Coal Fly Ash and Raw or Calcined Natural Pozzolan for Use in Concrete. ASTM International, West Conshohocken, PA, www.astm.org.

[31] ASTM C136 / C136M-14, 2014. Standard Test Method for Sieve Analysis of Fine and Coarse Aggregates, ASTM International, West Conshohocken, PA, www.astm.org.

[32] ASTM C33 / C33M-13, 2013. Standard Specification for Concrete Aggregates, ASTM International, West Conshohocken, PA, www.astm.org.

[33] ASTM C192 / C192M-14, 2014. Standard Practice for Making and Curing Concrete Test Specimens in the Laboratory, ASTM International, West Conshohocken, PA, 2014, www.astm.org.

[34] ISO 1920-1, 2004. Testing of concrete- part 1: Sampling of fresh concrete. International Organization for Standardization, Geneva, Switzerland.

[35] ISO 1920-4, 2005. Testing of concrete- Part 4: Strength of hardened concrete. International Organization for Standardization, Geneva, Switzerland.

[36] ALQAM, M. - JAMRAH, A. - AL-HAFITH, B.A. - AL-ZUBI, R. - AL-SHAMARI, N.: Fresh and hardened properties of sustainable concrete using recycled household greywater. Arabian Journal for Science and Engineering, Vol. 39, 2014, pp. 1701-1708.

[37] EPA, 2012. Guidelines for water reuse. EPA/600/R-12/618, United State Environmental Protection Agency, Washington, D.C.

[38] MEHRDADI, N. - AKBARIAN, A. - HAGH ELAHI, A.: Using treated domestic wastewater in concrete mixing (In Persian). Journal of Environmental Studies, 35(50), 2009, p. 129-136.

[39] BABU, G.R. - REDDY, B.M. - RAMANA, N.V.: Quality of mixing water in cement concrete. A review. Materials Today, Proceedings, Vol. 5, 2018, pp. 1313-1320. 